\title{
ATM haplotypes and breast cancer risk in Jewish high-risk women
}

\author{
M Koren', G Kimmel'2, E Ben-Asher, I Gal', MZ Papa ${ }^{4,5}$, JS Beckmann ${ }^{3}$, D Lancet ${ }^{3}$, R Shamir ${ }^{2}$ and \\ E Friedman*,I,5
}

'Susanne Levy Gertner Oncogenetics Unit, The Danek Gertner Institute of Human Genetics, Tel-Hashomer, Israel; ${ }^{2}$ The Faculty of Exact Sciences, School of Computer Science, Tel-Aviv University, Tel-Aviv, Israel; ${ }^{3}$ Department of Molecular Genetics and the Crown Center for Human Genome, Weitzman Institute of Science, Rehovot 76100, Israel; ${ }^{4}$ Department of Oncological Surgery, The Chaim Sheba Medical Center, Tel-Hashomer, Israel; ${ }^{5}$ Sackler School of Medicine, Tel-Aviv University, Tel-Aviv, Israel

While genetic factors clearly play a role in conferring breast cancer risk, the contribution of ATM gene mutations to breast cancer is still unsettled. To shed light on this issue, ATM haplotypes were constructed using eight SNPs spanning the ATM gene region ( $42 \mathrm{~kb}$ ) in ethnically diverse non-Ashkenazi Jewish controls $(n=118)$ and high-risk $(n=142)$ women. Of the 28 haplotypes noted, four were encountered in frequencies of $5 \%$ or more and accounted for $85 \%$ of all haplotypes. Subsequently, ATM haplotyping of high-risk, non-Ashkenazi Jews was performed on 66 women with breast cancer and 76 asymptomatic. One SNP (rs228589) was significantly more prevalent among breast cancer cases compared with controls $\left(P=4 \times 10^{-9}\right)$, and one discriminative ATM haplotype was significantly more prevalent among breast cancer cases (33.3\%) compared with controls $(3.8 \%),\left(P \leqslant 10^{-10}\right)$. There was no significant difference in the SNP and haplotype distribution between asymptomatic high-risk and symptomatic women as a function of disease status. We conclude that a specific ATM SNP and a specific haplotype are associated with increased breast cancer risk in high-risk non-Ashkenazi Jews.

British Journal of Cancer (2006) 94, I537- 1543. doi:I0.I038/sj.bjc.6603062 www.bjcancer.com

Published online 4 April 2006

(c) 2006 Cancer Research UK

Keywords: ATM gene; breast cancer risk; SNP; haplotypes; high-risk populations; Jewish breast cancer patients

Inherited predisposition to breast cancer is well established in BRCA1 (MIM\# 113705) and BRCA2 (MIM\# 600185) mutation carriers (reviewed by Narod and Foulkes, 2004). Yet, only $20-40 \%$ of familial inherited breast cancer risk is conferred by $B R C A 1 / 2$ mutations, and clearly other genes are involved in familial breast cancer clustering (Ford et al, 1998; Nathanson and Weber, 2001; Thompson and Easton, 2004; Garber and Offit, 2005). A strong candidate for a breast cancer predisposition gene is ATM (MIM\# 607585). The attribution of ATM candidacy as a breast cancer susceptibility gene stems from two sources. Functionally, the ATM protein is a pivotal player in mediating cellular responses to DNA damage, including DNA double-strand break repair and signaling, leading to cell-cycle arrest and apoptosis (reviewed in Rotman and Shiloh, 1999). From the genetic perspective, ATM is the gene mutated in ataxia-telangiectasia (AT), an autosomal recessive disorder phenotypically characterised by chromosomal instability and an increased risk for lymphoproliferative tumors in homozygotes (Swift et al, 1991; Gatti et al, 1999). Ataxia-telangiectasia heterozygotes that are asymptomatic have been reported to be at an increased risk for developing breast cancer (Swift et al, 1991; Gatti et al, 1999; reviewed by Hall, 2005), although these reports are still controversial and not universally accepted. ATM gene's contribution to breast cancer risk was previously evaluated in the context of high-risk families, in BRCA1/2 mutation carriers, and in

\footnotetext{
*Correspondence: Dr E Friedman, The Susanne Levy Gertner Oncogenetics Unit, The Danek Gertner Institute of Genetics, Chaim Sheba Medical Center, Tel-Hashomer 5262I, Israel;

E-mails: eitan.friedman@sheba.health.gov.il or eitan21 I@netvision.net.il Received 22 November 2005; revised 17 February 2006; accepted 27 February 2006; published online 4 April 2006
}

average risk populations (reviewed in Gatti et al, 1999; Hall, 2005). The results of these studies are inconclusive, with some studies reporting an increased breast cancer risk (Swift et al, 1987; Pippard et al, 1988; Athma et al, 1996; Stancovic et al, 1998; Inskip et al, 1999; Janin et al, 1999) and others failing to demonstrate such an effect in heterozygote ATM mutation carriers (Vorechovsky et al, 1996; FitzGerald et al, 1997; Bay et al, 1998; Chen et al, 1998).

In order to shed further light on the putative contribution of ATM to breast cancer risk, we performed haplotyping of the ATM locus in high-risk individuals and controls of non-Ashkenazi Jewish origin.

\section{MATERIALS AND METHODS}

\section{High-risk participants: identification, recruitment, and data collection}

All high-risk individuals studied herein were ascertained and identified from among individuals referred for genetic counseling and testing at the Oncogenetics unit, Sheba Medical Center, Tel Hashomer Israel. Only one individual per high-risk family was included in the study. All participants were counseled for family history of breast cancer, and all affected women had histopathologically proven breast cancer. Relevant demographic and clinical data were collected at the time of initial genetic counseling and included type of malignancy (based on pathology reports), age at diagnosis, age at counseling, and ethnic origin at least three generations back. High risk was assigned based on current accepted criteria (Lynch and Lynch, 2002). The study was approved by the institutional review board (Helsinki committees) at Sheba Medical Center, and each participant signed a written 
informed consent. Based on the results of the genetic testing (see below), none of the study participants was a carrier of any of the predominant Jewish mutations in BRCA1/2.

\section{Control population}

DNA samples were taken from unrelated, healthy, non-Ashkenazi individuals, with no personal or familial history of cancer. These were recruited primarily from among women who escorted the high-risk women but were unrelated to them (e.g. friends, married ins, etc.). All study participants among controls gave their consent for anonymous testing.

\section{Origin of patients}

All the patients in this study are non-Ashkenazi Jews originating from Iraq, the Balkan, and Yemen.

\section{DNA isolation}

Genomic DNA was prepared from anticoagulated, venous blood samples using the PUREGene DNA isolation kit (Gentra systems Inc., Minneapolis, MN, USA) using the manufacturer's recommended protocol.

\section{Genotyping for the recurring BRCA1/BRCA2 mutations}

None of the (high risk and control) participants of this study carried any of the four recurring BRCA1 (185delAG, 5382InsC,

\section{Table I ATM SNPs ${ }^{\mathrm{a}}$}

\begin{tabular}{|c|c|c|c|c|}
\hline SNP no. & SNP ID & Position $^{\mathbf{b}}$ & Polymorphism & Minor allele frequency \\
\hline I & rs3092993c & | | 799753 | & $\mathrm{A} / \mathrm{C}$ & 0.068 \\
\hline 2 & rs228589 & II 655624 & $A / T$ & 0.144 \\
\hline 3 & rs600931 & | | 67975 | & $\mathrm{A} / \mathrm{G}$ & 0.236 \\
\hline 4 & rs664677 & | I 705598 & $C / T$ & 0.242 \\
\hline 5 & rs227069 & | I 1772674 & $\mathrm{~A} / \mathrm{G}$ & 0.272 \\
\hline 6 & rs664982 & | 1787899 & $\mathrm{~A} / \mathrm{G}$ & 0.24 \\
\hline 7 & rs65254I & | | 78844 | & $\mathrm{C} / \mathrm{T}$ & 0.155 \\
\hline 8 & rs 170548 & 1 1 797252 & $\mathrm{G} / \mathrm{T}$ & 0.342 \\
\hline
\end{tabular}

${ }^{a}$ All SNPs are intronic and noncoding. ${ }^{b}$ Position based on Genbank Accession Number NT_033899 (http://www.ncbi.nih.gov/entrez/query.fcgi?db = snp\&cmd = search\&term $=r s) .{ }^{\circ}$ This SNP was originally coined ss 4328153 .
Tyr978X) and BRCA2 (6174delT) mutations reported in Jewish individuals. Detection of these mutations was carried out by modified restriction enzyme digest assay, which distinguishes the mutant from the wild-type allele, using primer sequences, cycling profiles, PCR conditions, and gel electrophoresis as previously described (Rohlfs et al, 1997; Shiri-Sverdlov et al, 2001). Only individuals not carrying these mutations were included in the subsequent study.

\section{ATM SNP selection and genotyping}

ATM genotyping was performed by PCR amplification of eight SNPs throughout the gene. The SNPs were chosen from three databases: www.ensembl.org www.genome.ucsc.edu and www.ncbi.nlm.nih.gov. The SNPs genotyped were ss4328153 (now rs3092993), rs228589, rs600931, rs664677, rs227069, rs664982, rs652541, and rs170548 (Table 1). SNP genotyping was carried out using the Sequenom ${ }^{\mathrm{TM}}$ MASSarray system (Sequenom, San-Diego, CA, USA).

\section{Sequenom $^{\mathrm{TM}}$ MassARRAY system}

PCR amplification was performed in 384-well microplates (Marsh Biomedical Products, Rochester, NY, USA), in a total volume of $5 \mu \mathrm{l}$, using $2.5 \mathrm{ng}$ reaction ${ }^{-1}$ DNA, $10 \times$ PCR Buffer containing $1.5 \mathrm{~mm} \mathrm{MgCl}_{2}, 200 \mathrm{~mm}$ dNTPs mix, $0.02 \mu \mathrm{l}$ HotStar Taq Polymerase at $5 \mathrm{U}^{-\mathrm{P}}$ (Qiagen Inc., Valencia, CA, USA), and 1 pmol each of forward and reverse PCR primer. After an initial denaturation at $94^{\circ} \mathrm{C}$ for $5 \mathrm{~min}, 45 \mathrm{cycles}$ of $94^{\circ} \mathrm{C}$ for $20 \mathrm{~s}$, annealing at $56^{\circ} \mathrm{C}$ for $30 \mathrm{~s}$, and extension at $72^{\circ} \mathrm{C}$ for $1 \mathrm{~min}$ were carried out with a final extension period of $3 \mathrm{~min}$. Primer sequences, designed using the software SpectroDESIGNER (Sequenom, San-Diego, CA, USA), are shown in Table 2.

PCR amplification was performed in multiplex reactions as follows:

Multiplex 1: SNPrs228589+ SNPrs3092993 + SNPrs170548.

Multiplex 2: SNPrs652541 + SNPrs227069 + SNPrs664982.

Multiplex 3: SNPrs664677+ SNPrs600931.

Following PCR, SNP genotyping proceeded as previously described (Little et al, 1997a, b; Buetow et al, 2001).

Similar to these above-mentioned studies, quality control and quality assurance were provided by randomly including non-DNA containing well in the chip as well as re-genotyping about $10 \%$ of the samples for all SNPs on different chips.

Table 2 Primer sequences used for detecting the relevant SNPs

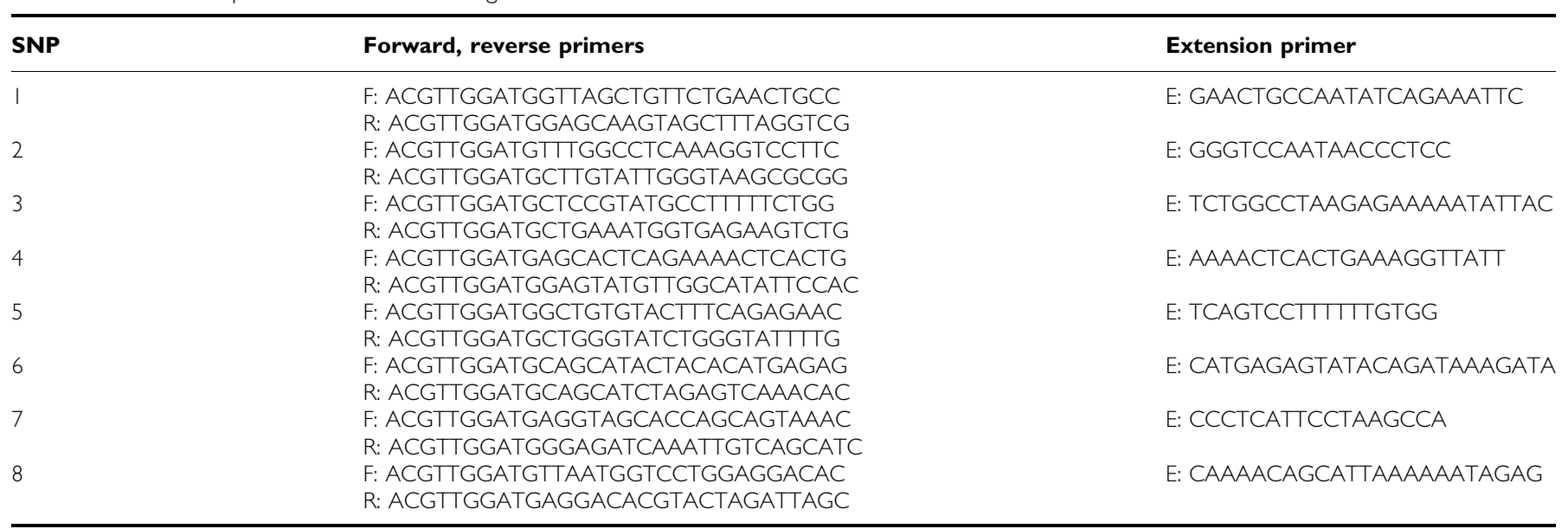




\section{Statistical methods, haplotype reconstruction, and} association analyses

The process of phasing the genotypes and imputing the missing data was performed by the software GERBIL (Kimmel and Shamir, 2005).

The association between sequence variants and breast cancer was evaluated by permutation test (Zhang et al, 2002) as follows: to evaluate the overall $P$-value of the association between the SNPs genotypes and the disease, the Pearson score of each marker is calculated, and the maximum value over all markers, denoted $\mathrm{CC}_{\text {max }}$, is chosen as the test statistic. Then, the same statistic is calculated for many data sets with the same genotypes and randomly permuted labels of the case and control individuals. The fraction of times that this value exceeds $C_{\max }$ is used as the $P$-value. This test has the advantage of not assuming a specific distribution function. Additionally, it handles multiple-testing directly and avoids the bias of correction, for example, by the overconservative Bonferroni method. This test was applied to cases $v s$ controls, and also to the high-risk group $v s$ controls.

Since there are three different population groups in the study, originating from Iraq, the Balkan and Yemen, the score for each marker was calculated as follows: Let $P_{i, j}$ be the Pearson score of the $j$ th marker for the $i$ th population (out of three possibilities). The statistic $\mathrm{CCP}_{\max }$ is defined to be $\max _{j} \sum_{i} P_{i, j}$. The $P$-value is calculated by a permutation test as mentioned above, with the difference of randomly permuting the labels within each population independently, and using the statistic $\mathrm{CCP}_{\max }$ instead of $\mathrm{CC}_{\max }$. This statistic avoids the bias in the $P$-value that might occur due to the mixture of different populations.

The permutation test can be readily generalised to handle association between haplotypes and the disease, for example, by adding block haplotypes as artificial loci with states corresponding to common haplotypes. Similarly, one can add loci interactions as artificial loci, whose states are the allele combinations.

Estimates of odds ratio (OR), relative risk (RR), and $95 \%$ confidence interval (CI) were calculated for the discriminative SNPs and haplotypes (Tables $3 \mathrm{~A}$ and $\mathrm{B}$ ).

We repeated the above procedure to perform two different tests:

(1) Association test for each SNP separately and for the haplotype composed from all the eight SNPs.

Table 3A Frequencies of the most associated SNP (number 2, rs228589)

\begin{tabular}{lcccc}
\hline Allele & Frequency & $\begin{array}{c}\text { Case } \\
(\boldsymbol{n}=\mathbf{6 6})\end{array}$ & $\begin{array}{c}\text { Healthy high } \\
\text { risk }(\boldsymbol{n}=\mathbf{7 6}) \%\end{array}$ & $\begin{array}{c}\text { Control } \\
(\boldsymbol{n}=\mathbf{I} \mathbf{1 8})\end{array}$ \\
\hline $\mathrm{A}$ & 0.856 & 66.7 & 51.4 & 96.2 \\
$\mathrm{~T}$ & 0.144 & 33.3 & 48.6 & 3.8 \\
\hline
\end{tabular}

(2) Association test of all possible pair-wise interactions of SNPs.

\section{RESULTS}

\section{Characteristics of study participants}

In total, 260 unrelated women of non-Ashkenazi Jewish origin were genotyped in this study. Of these, 142 were evaluated and considered at high risk for developing breast cancer based on their family history. Of the high-risk individuals, 66 (46.5\%) were breast cancer cases (mean age at diagnosis was $48.3 \pm 9.7$ years) and their ethnic origin was Iraqi $(n=34$ or $51.5 \%)$, Balkan $(n=16$ or $24.25 \%)$, or Yemenite origin $(n=16$ or $24.25 \%)$. Additional 76 $(53.5 \%)$ women were asymptomatic, high-risk women. The age range at counseling for the high-risk asymptomatic group was 28-67 years (mean $50.3 \pm 10.5$ years), and their ethnic distribution was as follows: 34 of Iraqi (44.7\%), 26 of Balkan (34.2\%), and 16 of Yemenite origin $(21 \%)$. The ethnicity of the population-matched healthy controls $(n=118)$ was $55(46.61 \%)$ Iraqis, $29(24.57 \%)$ of Balkan origin, and $34(28.81 \%)$ Yemenites. The age range at counseling for the control group was $33-69$ years (mean $53.4 \pm 8.9$ years).

All participants were genetically prescreened and shown not carry any of the four common Jewish mutations in BRCA1 (185delAG; 5382insC; Tyr978X) and in BRCA2 (6174delT).

\section{Phasing the genotypes}

Phasing the genotypes of the eight SNPs at the ATM locus yielded together 28 different haplotypes in one block of high LD (Table 4). Four haplotypes had a frequency $\geqslant 0.05$ (Table $5 \mathrm{~A}$ ) accounting together for $85 \%$ of all haplotypes. For association test of the haplotypes, we generated four clusters corresponding to the four common haplotypes and clustered each rare haplotype with the common haplotype to which it resembled most, as measured by Hamming distance.

\section{Association tests}

We first compared the breast cancer patients to the control population. SNP 2 (rs228589) is the most associated with the disease, with score of 61.61 (after multiple testing correction: $P=4 \times 10^{-9}$ ). In this SNP, nucleotide $\mathrm{T}$ appears in $3.8 \%$ of the controls and in $33.3 \%$ of the cases (Table $3 \mathrm{~A}$ ). Odds ratios and RR values for this SNP are listed in Table $3 \mathrm{~B}$.

An association test was performed for each SNP separately and for the complete 8-SNP haplotype. The Pearson scores of association are presented in Table 6. Interestingly, this SNP alone

Table 3B Comparison of the most associated SNP (number 2, rs228589) between the study's subgroups: case vs control, and asymptomatic high-risk vs control

\begin{tabular}{|c|c|c|c|c|c|c|}
\hline \multirow[b]{2}{*}{ Study subset } & \multicolumn{2}{|c|}{ Alleles (\%) } & \multicolumn{2}{|c|}{$\operatorname{RR}(95 \% \mathrm{Cl})$} & \multicolumn{2}{|c|}{ OR $(95 \% \mathrm{Cl})$} \\
\hline & $\mathbf{A}$ & $\mathbf{T}$ & $\mathbf{A}$ & $\mathbf{T}$ & $\mathbf{A}$ & $\mathbf{T}$ \\
\hline Asymptomatic high risk vs control & $\begin{array}{r}76(51) \\
227(96)\end{array}$ & $\begin{array}{c}72(49) \\
9(4)\end{array}$ & $0.28(0.23-0.35)$ & $3.45(2.87-4.37)$ & $0.04(0.02-0.09)$ & $23.89(11.4-50.08)$ \\
\hline
\end{tabular}

$\mathrm{RR}$, relative risk; $\mathrm{OR}$, odds ratio; $\mathrm{Cl}$, confidence interval. 
Table 4 The LD scores (measured in $r^{2}$ ) between all 8 SNPs

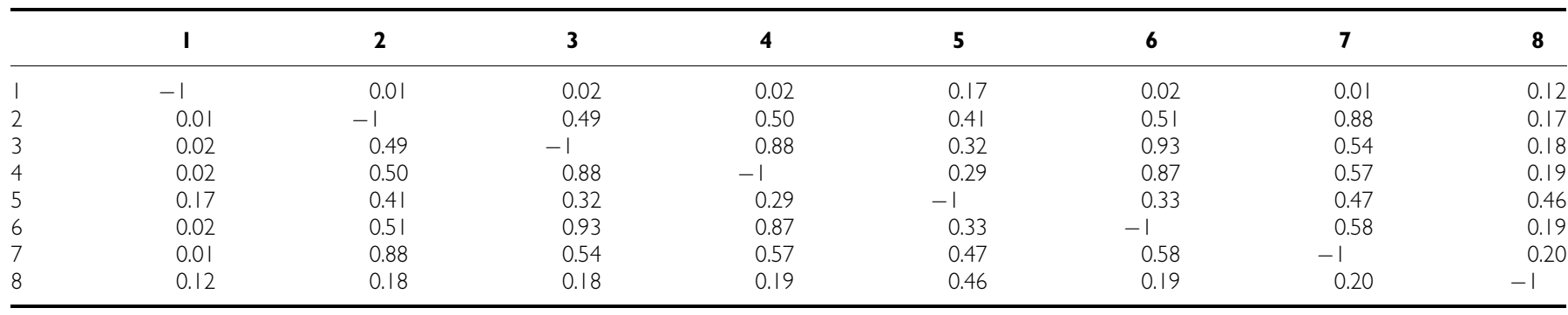

Table 5A The inferred haplotypes and their frequency

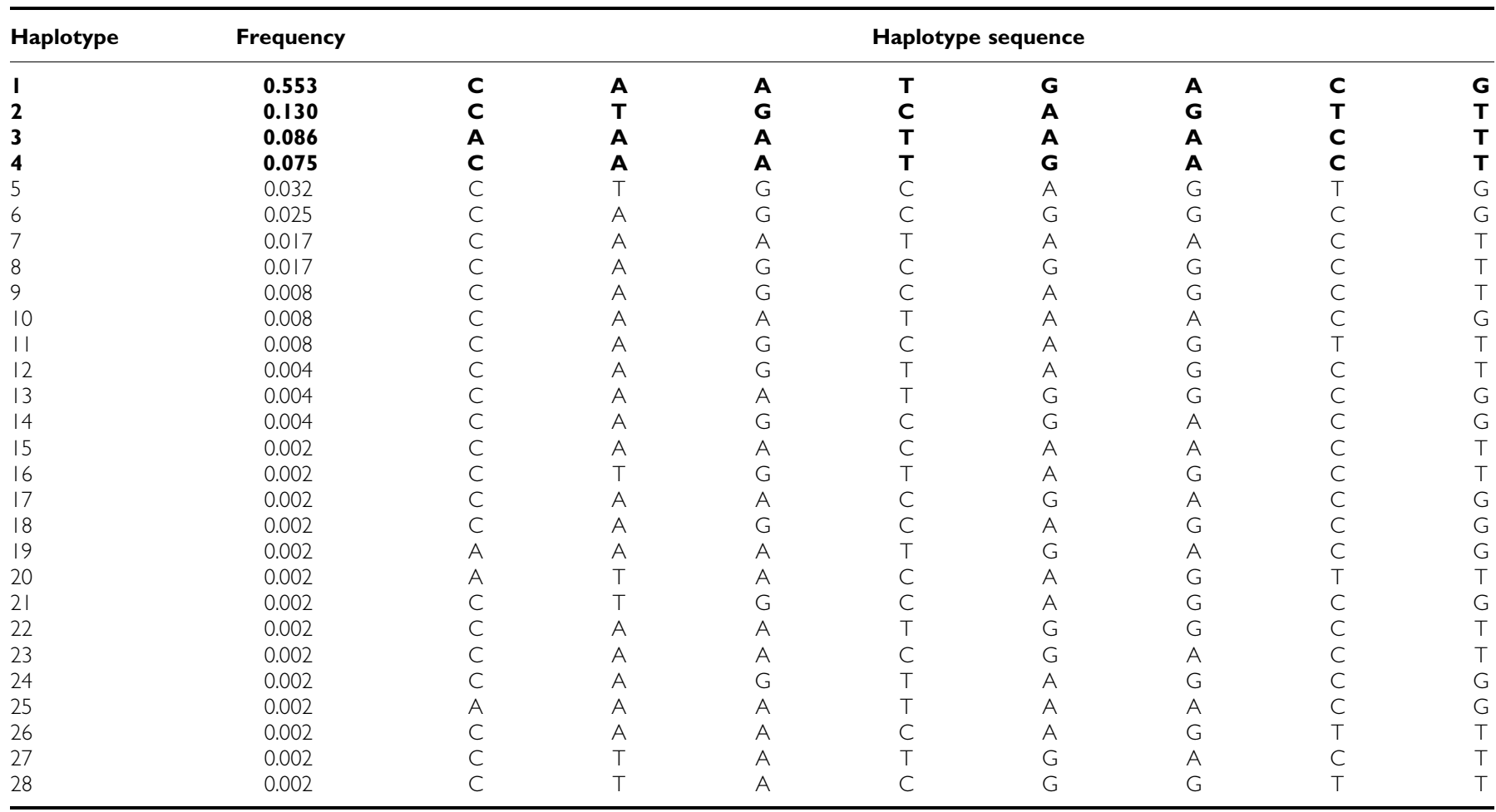

Table 5B Frequencies of the haplotypes composed of SNPs I and 2

\begin{tabular}{lccccc}
\hline Haplotype & $\begin{array}{c}\text { Haplotype } \\
\text { sequence }\end{array}$ & Frequency & $\begin{array}{c}\text { Case } \\
(\boldsymbol{n}=\mathbf{6 6}) \\
\%\end{array}$ & $\begin{array}{c}\text { Healthy } \\
\text { high risk } \\
(\boldsymbol{n}=\mathbf{7 6}) \%\end{array}$ & $\begin{array}{c}\text { Control } \\
(\boldsymbol{n}=\mathbf{1} \text { 18) } \\
\%\end{array}$ \\
\hline A & CA & 0.737 & 56 & 61.2 & 91.5 \\
B & CT & 0.171 & 33.3 & 24.3 & 3.8 \\
C & AA & 0.09 & 10.6 & 14.5 & 4.7 \\
\hline
\end{tabular}

shows higher association than the complete haplotype (score 31.45).

An additional test was performed for each pair of SNPs. The pair of SNPs most associated was SNP 1 (rs3092993) and 2 (rs228589) (both intronic SNPs) $\left(P \leqslant 10^{-10}\right)$. We therefore examined the short genotypes consisting of SNP 1 and SNP 2. These genotypes form three common haplotypes, coined A, B and C (Table 5B), and additional rare haplotype of frequency 0.002 , which we ignored for the association test. Haplotypes $\mathrm{B}$ and $\mathrm{C}$ were significantly more prevalent in cases $(33.3 \%)$ compared with controls $(3.8 \%)$ : odd ratios and $R R$ values for these two haplotypes are listed in
Table 5C Frequencies of the haplotypes composed of SNPs 2 and 3

\begin{tabular}{lcccc}
\hline Haplotype & $\begin{array}{c}\text { Haplotype } \\
\text { sequence }\end{array}$ & Frequency & $\begin{array}{c}\text { Healthy } \\
\text { high risk+case } \\
(\mathbf{n}=\mathbf{I 4 2}) \%\end{array}$ & $\begin{array}{c}\text { Control } \\
(\boldsymbol{n}=\mathbf{I} \text { I 8) \% }\end{array}$ \\
\hline D & AA & 0.763 & 72.5 & 80.9 \\
E & TG & 0.167 & 27.5 & 3.8 \\
F & AG & 0.069 & 0 & 15.3 \\
\hline
\end{tabular}

Table 7A. In agreement with the above, these two haplotypes were also significantly more prevalent in the healthy high risk (24.3 and $14.5 \%)$ compared with controls (3.8\% and $4.7 \%)$. In contrast, haplotype A was significantly more prevalent in controls $(91.5 \%)$ as compared to cases $(56 \%)$ or healthy high risk $(61.2 \%)$. Odd ratios and RRs followed compatible trends (Table 7A).

Next, we tested all case and high-risk patients clustered together as a single group $v s$ controls. When testing each SNP separately, the most associated SNP is again SNP $2\left(\right.$ rs228589) $\left(P=7 \times 10^{-9}\right)$. When testing all pairwise interactions of SNPs, the most associated pair is SNP 2 (rs228589) and SNP 3 (rs600931) $\left(P \leqslant 10^{-9}\right)$ 
(Table 5C). One rare haplotype of frequency 0.006 was ignored for this test. One short haplotype consisting of SNPs 2 and 3, coined E (Table 7B) confers a RR of 7.2 95\% CI (3.69-14.05), and an OR of 9.55 95\% CI (4.67-19.5).

Testing association of the individual SNPs and of all the SNP pairs on the group of high-risk women $v s$ cases yields no significant result $(P=0.35)$.

\section{DISCUSSION}

In this study, several ATM SNPs were seemingly associated with breast cancer risk in Jewish non-Ashkenazi women at high-risk for breast cancer. These results further establish ATM as a contributor to breast cancer susceptibility in high-risk populations.

Increased breast cancer risk in ATM heterozygote mutation carriers has been previously reported in studies that either inferred obligate carriership (Swift et al, 1987; Pippard et al, 1988) or directly tested for gene mutations (Athma et al, 1996; Stancovic et al, 1998; Inskip et al, 1999; Janin et al, 1999; Olsen et al, 2001). Epidemiological studies have consistently shown that female relatives of $\mathrm{A}-\mathrm{T}$ patients are at an increased risk for developing breast cancer (reviewed in Hall, 2005). Interestingly, this increased risk was predominantly observed in the mothers of A-T carriers and not in siblings and offsprings (Olsen et al, 2005). Yet, not all studies confirmed the associated breast cancer risk conferred by being an ATM heterozygous mutation carrier (Vorechovsky et al, 1996; FitzGerald et al, 1997; Bay et al, 1998; Chen et al, 1998).

Two ATM germline alterations (Ala2524Pro and 6903insA) reported in A-T families have been shown to segregate with breast

Table 6 Pearson scores for association of the individual SNPs and of the haplotype to the disease phenotype

\begin{tabular}{lr}
\hline SNP & Score \\
\hline 1 & 8.13 \\
$\mathbf{2}$ & $\mathbf{6 1 . 6 1}$ \\
3 & 12.23 \\
4 & 11.39 \\
5 & 26.14 \\
6 & 12.16 \\
7 & 51.97 \\
8 & 11.88 \\
Haplotype & 31.46 \\
\hline
\end{tabular}

cancer in these families (Laake et al, 2000). Stancovic et al (1998) described two additional A-T families, where a heterozygous missense mutation, Val2424Gly $(7271 \mathrm{~T}<\mathrm{G})$ was associated with a presumed increased breast cancer risk. Another ATM mutation (IVS10-6T $<\mathrm{G}$ ) was suggested to be associated with early-onset breast cancer risk in patients, who were exposed to low-dose ionising radiation (Broeks et al, 2000; Dörk et al, 2001). The latter two mutations were functionally shown to exert a dominant negative effect on ATM protein (Chenevix-Trench et al, 2002). The contribution of the Val2424Gly and the IVS10-6T $<$ G mutations to increased breast cancer risk was further established in a large population-based, case-control study (Chenevix-Trench et al, 2002).

As most studies focused on sporadic rather than familial breast cancer cases, and employed screening methods preferentially capable of detecting protein-truncating mutations (Ángele and Hall, 2000), there might be more ATM non-truncating mutations and/or polymorphisms or variants (e.g. missense mutations) that affect breast cancer risk. In support of this notion, ATM missense substitutions seem to be more prevalent among Swedish, Canadian and Slovenian breast cancer patients (Dörk et al, 2001) and among US heterogeneous women (Teraoka et al, 2001). These findings give credence to the hypothesis that there are two distinct populations of ATM heterozygous mutations: null mutations or truncating mutations are not associated with breast cancer risk, whereas the presence of even a single missense allele may have a dominant negative effect on protein function and thus be associated with breast cancer risk (Meyn, 1999; Khanna, 2000). However, a more recent study from the UK (Thompson et al, 2005) shows that while being an ATM heterozygote does contribute to a modest increase in breast cancer risk, there are no differences in the risk as a function of mutation type.

The majority of studies conducted to assess ATM's contribution to breast cancer have used a variety of mutation detection techniques, with predominant bias for the detection of protein truncating mutations, or else they have examined the effect of specific ATM variants that are prevalent in the studied population (Hall, 2005). Only a handful of studies have used haplotyping, a mutation independent method, to assess the effect of ATM on breast cancer risk. Angele et al (2003) report that of the three major ATM haplotypes, one was significantly associated with breast cancer risk in French women. Similar results were also reported from Korea (Lee et al, 2005). Conversely, Tamimi et al (2004) used a large collection of cases and controls (more than 1300 individuals in each group) from the Nurses Health study, and

Table 7 Comparison of the short haplotypes between the study's subgroups: (A) case vs control, and asymptomatic high-risk vs control (Table 5B) and (B) all high-risk vs control (Table 5C)

\begin{tabular}{|c|c|c|c|c|c|c|c|c|c|}
\hline \multirow[b]{2}{*}{ Study subset } & \multicolumn{3}{|c|}{ Haplotypes (\%) } & \multicolumn{3}{|c|}{ RR $(95 \% \mathrm{Cl})$} & \multicolumn{3}{|c|}{ OR $(95 \% \mathrm{Cl})$} \\
\hline & $\mathbf{A}$ & B & C & $\mathbf{A}$ & B & C & $\mathbf{A}$ & B & C \\
\hline \multicolumn{10}{|c|}{ 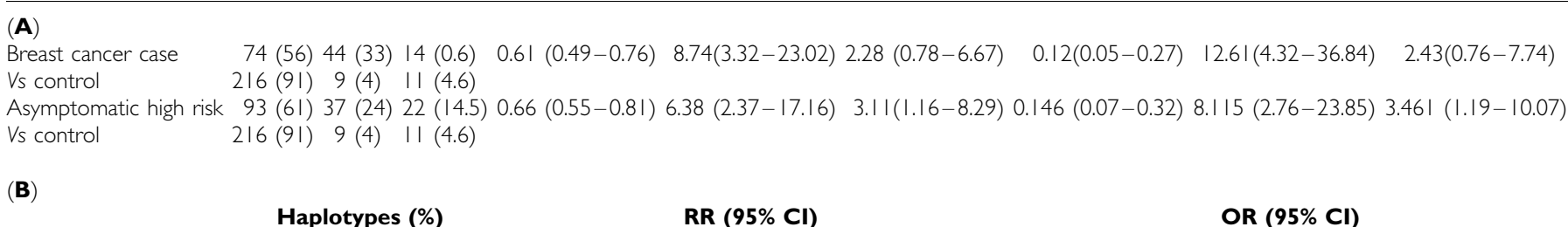 } \\
\hline Study subset & D & $\mathbf{E}$ & $\mathbf{F}$ & D & $\mathbf{E}$ & $\mathbf{F}$ & D & $\mathbf{E}$ & $\mathbf{F}$ \\
\hline $\begin{array}{l}\text { All high-risk women } \\
\text { Vs control }\end{array}$ & $\begin{array}{l}206(73) \\
191(81)\end{array}$ & $\begin{array}{l}78(27) \\
9(4)\end{array}$ & $\begin{array}{c}0(0) \\
36(15)\end{array}$ & $0.9(0.82-0.99)$ & $7.2(3.69-14.05)$ & - & $0.62(0.4 I-0.94)$ & $9.55(4.67-19.5)$ & - \\
\hline
\end{tabular}

$\mathrm{RR}$, relative risk; $\mathrm{OR}$, odds ratio; $\mathrm{Cl}$, confidence interval. 
report that none of five common ATM haplotypes was associated with breast cancer risk in American women.

The current study is the first to report ATM SNP and haplotype in a population of high-risk non-Ashkenazi Jewish women. Unlike the lack of a discriminating ATM haplotype among average risk Ashkenazi Jewish breast cancer women (Bonnen et al, 2001), the present study shows that ATM does contribute to familial clustering of breast cancer in non-Ashkenazim. It is noteworthy that specific genotypes are associated with breast cancer risk even without performing the phasing process. A very strong association $\left(P=4 \times 10^{-9}\right)$ was noted by testing each SNP separately, and correcting for multiple hypotheses using permutation tests. Given the intronic position of the two SNPs most tightly associated with breast cancer risk and phenotype, it is unlikely that these SNPs in and by themselves are disease associated. Rather, in all likelihood they are in linkage disequilibrium with a pathogenic ATM mutation.

It is important to emphasise that only one patient was analyzed per high-risk family, so that patients in the high-risk group are not more genetically related to each other than in the control group. Additionally, our statistical method for computing the $P$-value takes into account the three different subpopulations and corrects for multiple testing. Hence, the strong association noted between the ATM genotype and the high-risk phenotype seems real, and cannot be accounted for as an artifact caused by analysis of related individuals.

The limitations of the study should be pointed out. This was a relatively small study that analyzed a highly selected population, and includes only non-Ashkenazi Jewish women who were recruited through high-risk clinic in a single medical center in Israel. Thus, the applicability of the results to average-risk population or even high risk, ethnically diverse populations, needs to be established.

In conclusion, the present study suggests that a specific ATM SNP seemingly contributes to breast cancer predisposition in Jewish non-Ashkenazi high-risk women in Israel.

\section{ACKNOWLEDGEMENTS}

This study was in part funded by a grant from the Israel Ministry of Science to the Crown Genome Center in the Weitzman Institute of Science; this study was also partially supported by a grant to RS from the Wolfson Foundation; this study was carried out in partial fulfillment for the degree of Masters of Science from the Sackler School of Medicine, Tel-Aviv University, Tel-Aviv to M.K.

\section{REFERENCES}

Ángele S, Hall J (2000) The ATM gene and breast cancer: is it really a risk factor? Mutat Res 462: 167-178

Angele S, Romestaing P, Moullan N, Vuillaume M, Chapot B, Friesen M, Jongmans W, Cox DG, Pisani P, Gerard JP, Hall J (2003) ATM haplotypes and cellular response to DNA damage: association with breast cancer risk and clinical radiosensitivity. Cancer Res 63(24): $8717-8725$

Athma P, Rappaport R, Swift M (1996) Molecular genotyping shows that ataxia-telangiectasia heterozygotes are predisposed to breast cancer. Cancer Genet Cytogenet 92: $130-134$

Bay JO, Grancho M, Pernin D, Presneau N, Rio P, Tchirkov A, Uhrhammer N, Verrelle P, Gatti RA, Bignon YJ (1998) No evidence for constitutional ATM mutation in breast/gastric cancer families. Int J Oncol 12: 1385 1390

Bonnen PE, Figer A, Arbel S, Bruchim Bar Sade R, Friedman E, Nelson D (2001) Complex SNP haplotypes at ATM and BRCA1 show potential association of ATM and BRCA1 variants with sporadically occurring breast cancer in Ashkenazi Jewish women. ASHG meeting (2001) Abstract \# 31

Broeks A, Urbanus JHM, Floore AN, Dahler EC, Klijn JGM, Rutgers EJT, Devilee P, Russle NS, van Leeuwen FE, van't Veer LJ (2000) ATMheterozygous germline mutations contribute to breast cancer-susceptibility. Am J Hum Genet 66: 494-500

Buetow KH, Edmonson M, MacDonald R, Clifford R, Yip P, Kelley J, Little DP, Strausberg R, Koester H, Cantor CR, Braun A (2001) highthroughput development and characterization of a genome-wide collection of gene-based single nucleotide polymorphism markers by chip-based matrix-assisted laser desorption/ionization time-of-flight mass spectrometry. Proc Natl Acad Sci USA 98(2): 581-584

Chen J, Giesler Birkholz G, Lindblom P, Rubio C, Lindblom A (1998) The role of ataxia-telangiectasia heterozygotes in familial breast cancer. Cancer Res 58: 1376- 1379

Chenevix-Trench G, Spurdle AB, Gatei M, Kelly H, Marsh A, Chen X, Donn K, Cummings M, Nyholt D, Jenkins MA, Scott C, Pupo GM, Dörk T, Bendix R, Kirk J, Tucker K, McCredie MRE, Hopper JL, Sambrook J, Mann GJ, Khanna KK (2002) Dominant negative ATM mutations in breast cancer families. J Natl Cancer Inst 94: 205-215

Dörk T, Bendix R, Bremer M, Rades D, Klöpper K, Nicke M, Skawran B, Hector A, Yamini P, Steinmann D, Weise S, Stuhrmann M, Karstens JH (2001) Spectrum of ATM gene mutations in a hospital-based series of unselected breast cancer patients. Cancer Res 61: 7608-7615

FitzGerald MG, Bean JM, Hegde SR, Unsal H, MacDonald DJ, Harkin DP, Finkelstein DM, Isselbacher KJ, Haber DA (1997) Heterozygous ATM mutations do not contribute to early onset of breast cancer. Nat Genet 15: $307-310$

Ford D, Easton DF, Stratton M, Narod S, Goldgar D, Devilee P, Bishop DT, Weber B, Lenoir G, Chang-Claude J, Sobol H, Teare MD, Struewing J, Arason A, Scherneck S, Peto J, Rebbeck TR, Tonin P, Neuhausen S, Barkardottir R, Eyfjord J, Lynch H, Ponder BA, Gayther SA, ZeladaHedman $\mathrm{M}$ et al (1998) Genetic heterogeneity and penetrance analysis of the BRCA1 and BRCA2 genes in breast cancer families. The breast cancer linkage Consortium. Am J Hum Genet 62: 676-689

Garber JE, Offit K (2005) Hereditary cancer predisposition syndromes. J Clin Oncol 23(2): 276-292

Gatti RA, Tward A, Concannon P (1999) Cancer risk in ATM heterozygotes: a model of phenotypic and mechanistic differences between missense and truncating mutatins. Mol Genet Metab 68: 419-423

Hall J (2005) The Ataxia-telangiectasia mutated gene and breast cancer: gene expression profiles and sequence variants. Cancer Lett 227(2): $105-114$

Inskip HM, Kinlen LJ, Taylor AMR, Woods CG, Arlett CF (1999) Risk of breast cancer and other cancers in heterozygotes for ataxia-telangiectasia. Br J Cancer 79: 1304-1307

Janin N, Andrieu N, Ossian K, Laugé A, Croquette M-F, Griscelli C, Debré M, Bressac-de-Paillerets B, Aurias A, Stoppa-Lyonnet D (1999) Breast cancer risk in ataxia telangiectasia (AT) heterozygotes: haplotype study in French AT families. Br J Cancer 80: $1042-1045$

Khanna KK (2000) Cancer risk and the ATM gene: a continuing debate. J Natl Cancer Inst 92: 795-802

Kimmel G, Shamir R (2005) GERBIL: genotype resolution and block identification using likelihood. Proc Natl Acad Sci (USA) 102: 158- 162

Laake K, Jansen L, Hahnemann JM, Brøndum-Nielsen K, Lönnqvist T, Kääriäinen H, Sankila R, Lähdesmäki A, Hammarström L, Yuen J, Tretli S, Heiberg A, Olsen JH, Tucker M, Kleinerman R, Børresen-Dale A-L (2000) Characterization of ATM mutations in 41 Nordic families with ataxia telangiectasia. Hum Mutat 16: 232-246

Lee KM, Choi JY, Park SK, Chung HW, Ahn B, Yoo KY, Han W, Noh DY, Ahn SH, Kim H, Wei Q, Kang D (2005) Genetic polymorphisms of ataxia telangiectasia mutated and breast cancer risk. Cancer Epidemiol Biomarkers Prev 14(4): $821-825$

Little DP, Braun A, Darnhofer-Demar B, Frilling A, Li Y, McIver Jr RT, Koster H (1997a) Detection of RET proto-oncogene codon 634 mutations using mass spectrometry. J Mol Med 75: 745-750

Little DP, Braun A, Darnhofer-Demar B, Koster H (1997b) Identification of apolipoprotein E polymorphisms using temperature cycled primer oligo 
base extension and mass spectrometry. Eur J Clin Chem Clin Biochem 35: $545-548$

Lynch HT, Lynch JF (2002) Hereditary cancer: family history, diagnosis, molecular genetics, ecogenetics, and management strategies. Biochimie 84(1): $3-17$

Meyn MS (1999) Ataxia-telangiectasia, cancer and the pathobiology of the ATM gene. Clin Genet 55: 289-304

Narod SA, Foulkes WD (2004) BRCA1 and BRCA2: 1994 and beyond. Nat Rev Cancer 4(9): $665-676$

Nathanson KL, Weber BL (2001) 'Other' breast cancer susceptibility genes: searching for more holy grail. Hum Mol Genet 10: 715-720

Olsen JH, Hahnemann JM, Børresen-Dale A-L, Brøndum-Nielsen K, Hammarström L, Kleinerman R, Kääriäinen H, Lönnqvist T, Sankila R, Seersholm N, Tretli S, Yuen J, Boice Jr JD, Tucker M (2001) Cancer in patients with ataxia-telangiectasia and in their relatives in the Nordic countries. J Natl Cancer Inst 93: $121-127$

Olsen JH, Hahnemann JM, Borresen-Dale AL, Tretli S, Kleinerman R, Sankila R, Hammarstrom L, Robsahm TE, Kaariainen H, Bregard A, Brondum-Nielsen K, Yuen J, Tucker M (2005) Breast and other cancers in 1445 blood relatives of 75 Nordic patients with ataxia telangiectasia. $\mathrm{Br}$ J Cancer 93(2): 260-265

Pippard EC, Hall AJ, Barker DJP, Bridges BA (1988) Cancer in homozygotes and heterozygotes of ataxia-telangiectasia and xeroderma pigmentosum in Britain. Cancer Res 48: 2929-2932

Rohlfs EM, Learning WG, Friedman KJ, Couch FJ, Weber BL, Silverman LM (1997) Direct detection of mutations in the breast and ovarian cancer susceptibility gene BRCA1 by PCR-mediated site-directed mutagenesis. Clin Chem 43(1): 24-29

Rotman G, Shiloh Y (1999) ATM: a mediator of multiple responses to genotoxic stress. Oncogene 18: $6135-6144$

Shiri-Sverdlov R, Gershoni-Baruch R, Ichezkel-Hirsch G, Gotlieb WH, Bruchim Bar-Sade R, Chetrit A, Rizel S, Modan B, Friedman E (2001) The
Tyr978X BRCA1 mutation in non-Ashkenazi Jews: occurrence in highrisk families, general population and unselected ovarian cancer patients. Community Genet 4(1): 50-55

Stancovic T, Kidd AMJ, Sutcliffe A, McGuire GM, Robinson P, Weber P, Bedenham T, Bradwell AR, Easton DF, Lennox GG, Haites N, Byrd PJ, Taylor AMR (1998) ATM mutations and phenotypes in ataxiatelangiectasia families in the British Isles: expression of mutant ATM and the risk of leukemia, lymphoma, and breast cancer. Am J Hum Genet 62: $334-345$

Swift M, Morrell D, Massey RB, Chase CL (1991) Incidence of cancer in 161 families affected by ataxia-telangiectasia. $N$ Engl J Med 325: 1831-1836

Swift M, Reitnauer PJ, Morrell D, Chase CL (1987) Breast and other cancers in families with ataxia-telangiectasia. N Engl J Med 316: 1289-1294

Tamimi RM, Hankinson SE, Spiegelman D, Kraft P, Colditz GA, Hunter DJ (2004) Common ataxia telangiectasia mutated haplotypes and risk of breast cancer: a nested case-control study. Breast Cancer Res 6(4): R416 - R422

Teraoka SN, Malone KE, Doody DR, Suter NM, Ostrander EA, Daling JR, Concannon P (2001) Increased frequency of ATM mutations in breast carcinoma patients with early onset disease and positive family history. Cancer 92: $479-487$

Thompson D, Duedal S, Kirner J, McGuffog L, Last J, Reiman A, Byrd P, Taylor M, Easton DF (2005) Cancer risks and mortality in heterozygous ATM mutation carriers. J Natl Cancer Inst 97(11): 813-822

Thompson D, Easton D (2004) The genetic epidemiology of breast cancer genes. J Mammary Gland Biol Neoplasia 9(3): 221-236

Vorechovsky I, Luo L, Lindblom A, Negrini M, Webster ADB, Croce CM, Hammarström L (1996) ATM mutations in cancer families. Cancer Res 56: $4130-4133$

Zhang K, Deng M, Chen T, Waterman MS, Sun F (2002) A dynamic programming algorithm for haplotype block partitioning. Proc Natl Acad Sci USA 99(11): $7335-7339$ 